\title{
PROSFEKTIF METODE SAMPEL DARAH KERING DALAM BIOANALISIS
}

\author{
Supandi \\ Fakultas Farmasi dan Sains, Uhamka, Jakarta \\ supandiuhamka@gmail.com
}

\begin{abstract}
Biosampling of dried blood spot method became lately very interested in bioanalysis, some of the advantages given in this method compared to conventional venous canulla (venipuncture); less invasive making it more pleasant for the patient or subject, requires small volume, requires simple transportation process and storage did not need special equipment, suod stabilizes analit and reduces risk of infection. The method of dried blood spot is done by invasive light on the finger or heel prick and then spike on filter paper and dried at room temperature or under nitrogen flow with controlled humidity and stored in bag with desiccant packages, than it analyzed using validation bioanalyzing method. Dried blood spot method can be applied on bioanalysis test for pharmacokinetic, toksikokinetic, epidemiologic and Teurapeutic drug monitoring.
\end{abstract}

Keywords: dried blood spot, bioanalysis, pharmacokinetic, therapeutic drug monitoring

\begin{abstract}
ABSTRAK
Biosampling dengan metode sampel darah kering (dried blood spot) belakangan menjadi sangat diminati dalam bioanalisis, beberapa keuntungan yang diberikan pada metode ini dibandingkan metode vena (venipuncture) antara lain; minimum invasif sehingga lebih menyenangkan bagi pasien atau subjek, volume sampel sedikit, proses transportasi dan penyimpanan tidak memerlukan peralatan khusus, stabilitas analit baik, dan mengurangi resiko infeksi. Metode sampel darah kering dilakukan dengan invasif ringan pada ujung jari atau pada tumit kemudian diusapkan pada kertas filter dan dikeringkan pada suhu kamar atau dibawah aliran gas nitrogen dengan kelembaban yang terkontrol lalu disimpan pada kantong bertutup, selanjutnya dianalisis dengan metode bioanalisis yang tervalidasi. Metode sampel darah kering dapat diaplikasikan pada uji farmakokinetik, toksikokinetik, epidemiologi, dan pemantauan terapi obat .
\end{abstract}

Kata kunci: sampel darah kering, bioanalisis, farmakokinetik, Pemantauan terapi obat

\section{PENDAHULUAN}

Matriks biologi yang paling sering digunakan dalam menganalisis kadar obat adalah darah, serum, plasma, urine dan saliva. Dalam hal memperoleh matriks biologi (terutama darah) dari subjek dapat dilakukan dengan cara invasif melalu vena (Venipuncture), ini merupakan metode biosampling konvensional dengan tehnik yang menyakitkan, selain itu penggunaan volume sampel yang besar akan sulit dilakukan pada pengujian seri farmakokinetik ataupun toksikokinetik yang dilakukan pada hewan kecil (Evans et al., 2015), 
Penggunaan metode sampel darah kering dalam bioanalisis memberikan penyederhanaan proses pengumpulan darah dan analisis dibandingkan metode Venipuncture. Metode sampel darah kering diperkirakan menjadi pengganti yang menjanjikan bahkan bisa melampaui metode bio-matriks (plasma/serum) untuk pengujian farmakokinetik dan pemantauan terapi obat (Sharma et al., 2014). Keuntungan metode sampel darah kering dibanding metode konvensioanal diantaranya; (1) mudah dan minimal invasif dalam mengumpulkan sampel, dapat dilakukan tanpa tenaga phelebotomist karena sampel dikumpulkan dari ujung jari atau tumit dengan invasif minimal menggunakan lancet steril (Wenkui et al., 2015), (2) volume sampel yang digunakan sedikit, hal ini mudah diimplementasikan pada hewan kecil, anak-anak dan bayi (Wilhelm et al., 2014), (3) analit lebih stabil dibandingkan penyimpanan pada freezer (Wilhelm et al., 2014), (4) biaya yang lebih rendah dalam proses, karena sampel DBS dapat disimpan dalam suhu kamar dalam pengiriman dan penyimpanan sehingga tidak memerlukan dry ice/ice box (Déglon et al., 2012), (5) memberikan keamanan, dalam keadaan kering senyawa pathogen menjadi tidak aktif sehingga mengurangi resiko infeksi. Hal yang sama dengan proses pengambilan sampel yang diusapkan pada kertas filter akan mengurangi resiko infeksi HIV/AIDS dan infeksi pathogen lainya (Rizwana et al., 2013)

Kendala yang dihadapi dalam penerpan metode ini adalah; (1) volume kecil, menyebabkan analit yang tersedia semakin kecil sehingga diperlukan tehnik analisa yang lebih sensitif, (2) resiko kontaminasi, jika orang yang sama yang melakukan pemberian obat dan pengambilan sampel maka memungkinkan resiko kertas filter terkontaminasi obat, (3) jika dilakukan oleh pasien meski sudah diberikan pelatihan, pengambilan sampel tidak selalu berhasil, (4) konsentrasi analit di kapiler kemungkinan berbeda dengan di vena, (5) validasi yang lebih sulit karena variasi nilai hematokrit dapat menyebabkan perbedaan homogenitas dan sebaran sampel pada spot kertas filter, penggunaan kertas yang berbeda juga diperlukan validasi parsial (Timmerman et al., 2011).

Metode sampel darah kering dapat membantu aplikasi pada uji farmakokinetik dan toksikokinetik, monitoring penggunaan obat, skrining penyakit, test penggunaan doping dan pengujian metabolisme. Hal ini telah diterapkan pada industri farmasi, rumah sakit dan pusat penelitian, terutama untuk sampel dengan volume kecil, daerah pengambilan sampel sulit atau terpencil, penyimpanan, proses dan transportasinya (Sharma et al., 2014; Wilhelm et al., 2014; Evan et al., 2015).

\section{SAMPEL DARAH KERING}

Dalam analisis menggunakan metode sampel darah kering langkahlangkah yang harus diperhatikan adalah sebagai berikut:

\section{Pemilihan kertas}

Kertas filter yang digunakan terdiri dari selulosa dan non selulosa yang memiliki ukuran pori dan ketebalan tertentu. Di pasaran dikenal jenis Whatman 903, FTA DMPK dan FTA Elute, dimana penggunakan jenis kertas disesuaikan dengan analisis yang dilakukan. Whatman 903 digunakan untuk pengujian skrining dan subjek bayi, FTA DMPK digunakan untuk pengujian farmakokinetik dan toksikokinetik sedangkan FTA Elute duganakan untuk mengumpulkan dan mempurifikasi DNA pada analisis akhir (Clark and Julian, 2011; Zhang et al., 2012). Food and Drug Administration menyetujui tiga jenis kertas filter yang dapat digunakan untuk mengkoleksi spesimen darah, yaitu; Ahlstrom 226-k062932, whatman 
903 dan Perkinelmer 226-21 CFR 862.1675 (FDA).

\section{Pengumpulan sampel}

Aplikasi pada subjek manusia sampel darah diambil dari jari tangan, jari kaki atau tumit dengan invasif ringan menggunakan lancet steril. Sedangkan untuk studi farmakokinetik dan toksikonetik pada hewan coba (tikus dan mencit) darah diambil melalui vena ekor (Dainty et al., 2012). untuk pengujian kualitatif, sampel darah yang diambil dari jari/tumit langsung di tampung pada kertas filter sedangkan untuk pengujian secara kuantitatif sampel darah di teteskan ke kertas filter secara kuantitatif menggunakan pipet/kapiler (Demirev, 2013).

Pada kasus tertentu penambahan antikoagulan diperlukan untuk memperoleh bercak yang tepat. Heparin dan EDTA adalah antikoagulan yang dapat digunakan. EDTA dapat menyebabkan gangguan pada Spektroskopi Massa tetapi EDTA lebih baik dari heparin dalam hal pencampuran dan kemampuan pengeringan bersama dengan kalsium. Penggunaan antikoagulan mempengaruhi hasil pengujian menggunakan quantitative Polymerase Chain Reaction (Zanet et al., 2013).

Penetesan berulang pada tempat yang sama di kertas DBS harus dihindari, karena akan menyebabkan specimen tidak valid dan salah tafsir hasil. Kerusakan bercak dapat berupa; bergumpal, jenuh, berubah warna, mengandung bintik-bintik. Sampel darah dengan nilai hematokrit yang berbeda memiliki viskositas dan sebaran yang berbeda mengakibatkan berbeda ukuran bercak pada kertas filter (Kesel et al., 2013).

\section{Pengeringan}

Setelah pengumpulan sampel, kertas filter umumnya dikeringkan horizontal selama 2-3 jam pada rak kartu pada suhu kamar atau di bawah aliran gas nitrogen dengan kelembaban dikontrol (Wenkui and Francis, 2010). Waktu yang diperlukan untuk pengeringan akan tergantung pada jenis serta volume sampel.

Kertas filter tidak boleh ditumpuk atau bagian bercak tersentuh permukaannya saat pengeringan, harus terhindar dari paparan lingkungan seperti sinar matahari langsung, debu, atau serangga terbang karena akan mengurangi integritas sampel. Proses pengeringan merupakan langkah penting dalam menjaga kestabilan analit, sehingga optimasi $\mathrm{pH}$, suhu dan kelembaban perlu dilakukan untuk memperoleh kestabilan analit pada kertas filter (Liu et al., 2011).

\section{Penyimpanan dan pengiriman}

Dibandingkan metode konvensional, proses penyimpanan dan pengiriman dengan metode sampel darah kering mengalami penyederhanaan/kemudahan. Metode sampel darah kering tidak membutuhkan freezer/ice box dan volume yang besar untuk penyimpanan ataupun pengiriman sehingga tidak membutuhkan peralatan khusus yang membutuhkan biaya yang mahal (EQA, 2005). Faktor kelembaban merupakan faktor yang secara signifikan akan mempengaruhi stabilitas analit dan akan menyebabkan peluang pertumbuhan bakteri, maka kertas DBS dalam penyimpanan dan pengiriman harus dijaga pada suhu yang konstan. Untuk perlindungan dari kelembaban lingkungan, kertas filter disarankan untuk dibungkus dan dikemas dalam tas plastik bersegel (plastik polystyrene) yang memiliki indikator pengering dan kelembaban (Rizwana et al., 2013)

\section{Pemberian baku dalam}

Penambahan baku dalam pada metode sampel darah kering adalah perlakuan yang rumit guna memperoleh hasil analisis yang valid. Ada 2 cara 
menambahkan baku dalam; (1) baku dalam ditambahkan sebelum ekstraksi, baik secara langsung dalam tabung ekstraksi atau dipelarut ekstraksi. Dalam beberapa laporan penelitian metode ini tidak menunjukkan effisiensi ekstraksi dari metode sampel darah kering (Liu et al., 2011). (2) Baku dalam ditambahkan pada kertas filter sebelum penambahan sampel darah, penambahan dilakukan dengan cara disemprotkan pada kertas filter di daerah/spot yang akan di berikan sampel darah. Metode ini memberikan homogenitas dan memastikan reproduktifitas untuk hasil yang lebih baik dan pada metode ini tidak ditemukan variabilitas ekstraksi analit dari metode sampel darah kering (Dieter et al., 2013.)

\section{Ekstraksi}

Ketas filter yang telah kering dibuat lingkaran dengan diameter tertentu pada bagian bercaknya dengan memotong kertas filter yang dapat dilakukan secara manual, semi-otomatis, dan otomatis (Oliveira et al., 2014). Diameter kertas DBS sangat tergantung dengan jumlah volume darah sampel yang diberikan (Neil Spooner 2013).

Ekstraksi analit dilakukan menggunakan pelarut yang sesuai, pemilihan pelarut harus dioptimalkan sesuai profil kelarutan analit dengan pertimbangan ekstraksi meminimalkan dari campur kotoran endogen (Chambers et al., 2013). Efisiensi ekstraksi dari sampel darah kering dapat ditingkatkan dengan penambahan amonium cair (Borremans 2014). Dalam beberapa uji perlakuan pengocokan, sonikasi dan penguapan dilakukan untuk meningkatkan efisiensi hasil ekstraksi. Ekstraksi dengan sampel darah kering dapat dilakukan dengan ekstraksi caircair atau pun ekstraksi fase padat (Edward et al, 2011; Soto et al., 2014).

\section{METODE ANALISIS}

Sampel yang telah diekstraksi siap untuk dianalisis, metode analisis yang digunakan harus sudah tervalidasi untuk meyakini kebenaran hasil analisis, prosedur validasi yang dilakukan mengikuti aturan dari Food and Drug Administration (FDA) ataupun European Medicine Agency (EMA), optimasi yang dilakukan meliputi; volume sampel, homogenitas bercak, hematokrit dan carry-over (Jager et al., 2014).

Volume sampel berkisar antara 15-40 $\mu \mathrm{L}$ yang ditentukan selama validasi, volume sampel yang berbeda harus diuji minimal pada dua tingkat konsentrasi (rendah dan tinggi) dan dilakukan pengulangan. Volume sampel yang digunakan pada standar kalibrasi harus sama dengan volume sampel yang digunakan pada aplikasi sampel klinis. Homogenitas bercak dapat dipengaruhi saat penotolan sampel dan penyebarannya serta lokasi pemotongan diameter kertas filter, hal ini akan mempengaruhi pengujian kuantitatif sampel darah kering sehingga perlu dilakukan validasi pemotongan diameter kertas filter dari tepi atau dari pusat bercak sampel dengan menyiapkan sampel minimal dua konsentrasi (rendah dan tinggi) dan pengulangan 3 kali, jika masih ada penyimpangan analisis dapat diujikan pada jenis kertas filter yang berbeda (O'mara et al., 2011). Carry-over dilakukan untuk melihat adanya komponen yang terbawa analit pada sampel darah setelah penyuntikan sampel pada konsentrasi tertinggi pada rentang kurva kalibrasi. Carry-over dilakukan dengan menyuntikan blanko kertas filter setelah penyuntikan sampel dengan konsentrasi tertinggi, sesuai pedoman pedoman EMA tidak boleh lebih besar dari $20 \%$ dari batas bawah kuantifikasi. Penggunaan darah utuh sebagai sampel yang diambil dari perifer dengan volume kecil, menyebabkan analit yang akan dianalisa sangat kecil dan adanya hematokrit akan sangat menggangu analisa secara kuantitatif molekul obat. Hematokrit akan mempengaruhi penyebaran darah pada kertas filter 
sehingga diperlukan kondisi optimum yang valid dalam penerapan metode sampel darah kering untuk dapat menganalisis molekul obat secara kuantitatif (Philip \& Neil 2010). Nilai hematokrit akan dipengaruhi antara lain oleh jenis kelamin, umur, status gizi dan pasien yang menjalani kemoterapi. Pasien kemoterapi akan mengalami anemia karena terjadi penurunan produksi platelet sehingga akan memiliki hematokrit yang rendah berkisar 0,2-0,3, hematokrit pada darah kapiler lebih tinggi dari hematokrit pada darah vena sekitar 0,61 dan pada anak-anak nilai hematokrit 0,35-0,45 (Kesel et al., 2013).

Beberapa metode yang digunakan untuk analisis sampel darah kering adalah; LC-MS/MS (Jager et al., 2014), HPLC-MS/MS (Vu et al., 2014), UPLCMS/MS (La marca et al., 2012) GC-MS (Ingels et al., 2010), LC-HRMS (Tanna et al., 2015) UHPLC-MS/MS (Odoardi et al., 2014).

\section{PENGGUNAAN METODE SAMPEL DARAH KERING}

\section{Studi toksikokinetik atau pra klinis farmakokinetik}

Pada pengujian pra klinis farmakokinetik pada hewan coba memerlukan volume darah 1-2 mL per sampel pada beberapa titik sehingga sulit dilakukan seri percobaan menggunakan hewan yang sama, metode sampel darah kering dengan jumlah yang kecil memungkinkan pengambilan seri sampel dapat dilakukan pada hewan yang sama sehingga mengurangi variasi dari subjek. Penggunaan metode sampel darah kering telah membantu pengurangan jumlah subjek hewan sampai $60 \%$ dan tentunya akan mengurangi biaya penelitian (Dainty et al., 2012). Penelitian yang dilakukan oleh Nikolay et al. (2010) dengan membandingkan metode sampel kering dengan darah utuh (plasma) melaporkan bahwa hasil dari keduanya serupa dalam kaitannya dengan; area di bawah kurva
(AUC), stabilitas, presisi, variabilitas dan akurasi data. Bahkan untuk darah utuh dengan rasio sel darah merah dengan plasma yang tinggi akan menyebabkan hemolisis darah sehingga menyebabkan kesalahan yang signifikan dalam perhitungan farmakokinetikfarmakodinamik, penggunaan sampel darah kering dapat mengatasi permasalahan ini (Liang et al., 2011).

\section{Pemantauan Terapi Obat}

Dalam pemantauan terapi obat penggunaan sampel darah kering sangat membantu dalam hal rekrutmen relawan karena metode yang minimal invasif dapat dilakukan sendiri oleh relawan (setelah mendapatkan pelatihan sederhana). Sampel darah kering sangat cocok untuk pemantauan terapi obat pada neonates terutama untuk penyakit bawaan atau genetik karena dilakukan dengan minimum infasif. Pemanfaatan sampel darah kering sangat dirasakan untuk pengujian pada sampel di daerah terpencil, dimana transportasi dan fasilitas penyimpanan seperti frezer sulit diperoleh maka biosampel dengan sampel darah kering akan memberikan efisiensi dan keuntungan dibandingkan biosampling melalui vena, sampel darah kering dapat mengurangi anggaran uji klinis secara keseluruhan hingga 50\% (Wilhelm et al., 2014)

\section{PENUTUP}

Metode sampel darah kering merupakan biosampling dengan teknik yang paling etis dan ekonomis untuk koleksi sampel darah, pengiriman, dan penyimpanan. Dalam diagnosis penyakit dan monitoring penggunaan obat tehnik ini memberikan kenyamanan pada pasien sekaligus keuntungan untuk para praktisi medis. Pengembangan tehnik sampel darah kering harus terus ditingkatkan dalam pemecahan masalah yang ada di dalam metode sampel darah kering seperti, homogenitas spot, pengaruh nilai hematokrit darah dan perolehan kembali 
analit. Validasi metode bioanalisis yang memenuhi peraturan baik dari Food and Drug Administration ataupun European Medicine Agen diperlukan mendapatkan hasil analisis yang akuran sehingga aplikasi pada pengujian bioanalisis dapat dipercaya.

\section{DAFTAR PUSTAKA}

1. Borremans B. (2014) Ammonium improves elution of fixed dried blood spots without affecting immunofluorescence assay quality. Trop. Med. Int. Health. DOI: 10.1111/tmi. 12259

2. Chambers A.G., Andrew J.P., Juncong Y., Alexander G.C., \& Christoph H.B. (2013) Multiplexed Quantitation of Endogenous Proteins in Dried Blood Spots by Multiple Reaction Monitoring - Mass Spectrometry. The American Society for Biochemistry and Molecular Biology, 12 (3), pp. 781-791

3. Clark T.G \& Julian J.H. (2011) Utilization of DBS within drug discovery: a simple 2D-LC-MS/MS system to minimize blood- and paperbased matrix effects from FTA elute $^{\mathrm{TM}}$ DBS. Bioanalysis, 3(11), pp. 1253-1270

4. Clavel M.S., \& Petra H. (2015) Analysis of metformin, sitagliptin and creatinine in human dried blood spots. Journal of Chromatography B, 997, pp. 218-228

5. Dainty T.C., Richmond E.S., Davies I. \& Blackwell M.P. (2012) Dried blood spot bioanalysis: an evaluation of techniques and opportunities toxicokinetic studies. Int $J$ Toxicol. 31(1), pp 4-13

6. Déglon J., Aurélien T., Patrice M., \& Christian S. (2012) Direct analysis of dried blood spots coupled with mass spectrometry: concepts and biomedical applications. Anal. Bioanal. Chem., 402, pp. 2485-2498
7. Demirev A.F. (2013) Dried blood spots: Analysis and applications. Anal.Chem. 85, 779

8. Dieter Z., Stephan H., Beatrice B., Stephan S., Christoph F., \& Matthias L. (2013) Internal standard application to dried blood spots by spraying: investigation of the internal standard distribution. Bioanalysis, 5(6), pp. 711-719

9. Edwards R.L., Andrew J.C., Mark B., Paul G., Josephine B., \& Helen J.C. (2011) Hemoglobin Variant Analysis via Direct Surface Sampling of Dried Blood Spots Coupled with High Resolution Mass Spectrometry. Anal. Chem., 83, pp. 2265-2270

10. EMA (2011) Guideline on bioanalytical method validation European Medicine Agency London: pp. 4-10

11. Enaksha R.W., Basira G.A., Naijia H.H., John W.R., Jennifer L.H., Kenneth J.R., Everett J.P., \& Ajai K.C. (2011) Dried blood spot sampling: coupling bioanalytical feasibility, blood-plasma partitioning and transferability to in vivo preclinical studies. Bioanalysis, 3(14), pp. 1635-1646

12. EQA (2005) Blood Collection and Handling Dried Blood Spot (Modul 14). Available at: http://www.who.int/diagnostics_labor atory/documents/guidance/pm_modul e14.pdf [10 September 2015].

13. Evans C., Mark A., Peter B., Jeffrey D., Christopher A.J., Wenkui L., Steve L., Luca M., Timothy O., Philip T., Xiaomin W., Enaksha W., John W., Eric W., \& Patricia Z. (2015) Implementing Dried Blood Spot Sampling for Clinical Pharmacokinetic Determinations: Considerations from the IQ Consortium Microsampling Working Group. The AAPS Journal, Vol. 17, No. 2, pp. 292-300

14. FDA (2001) Guidance for Industry Bioanalytical Method Validation. 
Food and Drug Administration United States of America: Department of Health and Human Services.

15. FDA. 510(K) SUMMARY. Available at:

http://www.accessdata.fda.gov/cdrh_ docs/pdf12/k121864.pdf [8 oktober 2015]

16. Ingels A., Lambert W.E. \& Stove C.P. (2010) Determination of gammahydroxybutyric acid in dried blood spots using a simple GC-MS method with direct 'on spot' derivatization. Anal. Bioanal. Chem. 398(5), pp. 2173-2182

17. Jager N.G.L., Hilde R., Jan H.M.S., \& Jos H.B. (2014) Determination of tamoxifen and endoxifen in dried blood spots using LC-MS/MS and the effect of coated DBS cards on recovery and matrix effects. Bioanalysis, 6(22), pp. 2999-3009

18. Jager N.G.L., Hilde R., Jan H.M.S., \& Jos H.B. (2014) Procedures and practices for the validation of bioanalytical methods using dried blood spots: a review. Bioanalysis. 6(18), pp. 2481-2514

19. Kesel P.M.M., Nele S., Sara C., Willy E.L., \& Christophe P.S. (2013) Hemato-critical issues in quantitative analysis of dried blood spots: challenges and solutions. Bioanalysis, 5(16), pp. 2023-2041

20. La Marca G, Giocaliere E. \& Villanelli F. (2012) Development of an UPLC-MS/MS method for the determination of antibiotic ertapenem on dried blood spots. J. Pharm. Biomed. Anal. 61, pp. 108-113

21. Liang X., Yang L., Berezhkovskiy L, Liederer B., Nguyen T, Jia Y., Schweiger W.,Dean B. \& Deng Y. (2011) Evaluation of dried blood spot sampling following cassette dosing in drug discovery. Bioanalysis, 3, 2291.

22. Liu G., Heidi M.S., \& Qin C.J. (2011) Internal standard tracked dilution to overcome challenges in dried blood spots and robotic sample preparation for liquid chromatography/tandem mass spectrometry assays. Rapid Commun. Mass Spectrom, 25, pp. $1250-1256$

23. Liu G., Ji Q.C., Jemal M., Tymiak A.A. \& Arnold M.E. (2011) Approach to evaluating dried blood spot sample stability during drying process and discovery of a treated card to maintain analyte stability by rapid on-card $\mathrm{pH}$ modification. Anal. Chem. 83, 9033.

24. Maria C.H., Emile H.M., and Jan A.O., 2015. Hematocrit-independent recovery of immunosuppressants from DBS using heated flow-through desorption. Bioanalysis, 7(16), pp. 2019-2029

25. Martin N.J. \& Helen J.C. (2014) Challenges and opportunities in mass spectrometric analysis of proteins from dried bloodspots. Expert Rev. Proteomics, 11(6), pp. 685-695

26. Neil Spooner (2013). A dried blood spot update: still an important bioanalytical technique. Bioanalysis, 5(8), pp. 879-883

27. Nikolay Y., osée M., Sylvain L., Jean N.M., Annik B., Milton F., Marianne R., Pascal G., Marc L., Robert B.M. \& Fabio G. (2010) Determination of naproxen using DBS: evaluation \& pharmacokinetic comparison of human plasma versus human blood DBS. Bioanalysis, 2(8), pp. 15011513

28. Odoardi S., Luca A. \& Sabina S.R. (2014). Simplifying sample pretreatment: Application of dried blood spot (DBS) method to blood samples, including postmortem, for UHPLC-MS/MS analysis of drugs of abuse. Forensic Science International, 243, pp. 61-67

29. Oliveira R.V., Jack H. \& Enaksha W. (2014) Fully-Automated Approach for Online Dried Blood Spot Extractionand Bioanalysis by TwoDimensional-Liquid 
ChromatographyCoupled with HighResolution Quadrupole Time-ofFlight Mass Spectrometry. Anal. Chem. 86, pp. 1246-1253

30. O’Mara M., Hudson B.C., Olson K., Yueh Y., Dunn J. \& Spooner N. (2011) The effect of hematocrit and punch location on assay bias during quantitative bioanalysis of dried blood spot samples. Bioanalysis, 3(20), pp. 2335-2347

31. Philip D. \& Neil S. (2010) The effect of hematocrit on assay bias when using DBS samples for the quantitative bioanalysis of drugs. Bioanalysis, 2(8), pp. 1385-1395

32. Rizwana Q., Raka J. \& Atul A. (2013) The use of dried blood spot samples in screening drugs of abuse. Pharmacology \& Pharmacy. 4, pp. 152-159

33. Rowland M. \& Gary T.E. (2010) Use of Dried Blood Spots in Drug Development: Pharmacokinetic Considerations. The AAPS Journal, Vol. 12, No. 3, pp. 290-293

34. Sharma A., Swati J., Mahendra S. \& Jawahar L. (2014) Dried blood spots: Concepts, present status, and future perspectives in bioanalysis. Drug Test. Analysis. DOI 10.1002/dta.1646

35. Soto M., Roger P., Valerie A., Mylowagner, Ronya P., Manuel P., James M., Christopher A.J., Kevin L.S. \& Marc W.R. (2014) Evaluation of matrix microsampling methods for therapeutic drug candidate quantification in discovery-stage rodent pharmacokinetic studies. Bioanalysis, 6(16), pp. 2135-2146

36. Tanna S., Dennis B. \& Graham L. (2015) LC-HRMS Analysis of Dried Blood Spot Samples for Assessing Adherence to Cardiovascular Medications. J. Bioanal. Biomed. Volume 7(1), pp. 001-068
37. Timmerman P., White S., Globig S., Ludtke S., Brunet L. \& Smeraglia J. (2011) EBF recommendation on the validation of bioanalytical methods for dried blood spots. Bioanalysis.;3:1567-75.

38. Vu D.H., Koster R.A., Bolhuis M.S., Greijdanus B., Altena R.V., Nguyen D.H, Brouwers J.R.B.J., Uges D.R.A. \& CAlffenaar J.W. (2014) Simultaneous determination of rifampicin, clarithromycin and their metabolites in dried blood spots using LC-MS/MS.Talanta, 121, pp. 9-17

39. Wenkui Li and Francis L.S.T., 2010. Dried blood spot sampling in combination with LC-MS/MS for quantitative analysis of small molecules. Biomed. Chromatogr., 24, pp. 49-65

40. Wenkui Li., John D., Paul M., Jimmy F. \& Francis L.S.T. (2015) LCMS/MS bioanalysis of loratadine (Claritin in dried blood spot (DBS) samples collected by subjects in a clinical research study. Journal of Chromatography B, 983-984, pp. 117-124

41. Wilhelm A.J., Jeroen C.G., Burger D. \& Eleonora L.S. (2014) Therapeutic Drug Monitoring by Dried Blood Spot: Progress to Date and Future Directions. Clin. Pharmacokinet, 53, pp. 961-973

42. Zanet D.L., Saberi L., Oliveira L., Sattha B., Gadawski I. \& Cote. H.C. (2013) Blood and dried blood spot telomere length measurement by qPCR: Assay considerations. PLoS One, 8, e57787.

43. Zhang Z., Wei X., Nicholas E.M., Graham R.C. \& Zheng O. (2012) Silica Coated Paper Substrate for Paper-Spray Analysis of Therapeutic Drugs in Dried Blood Spots. Anal. Chem. 84, pp. 931-938 